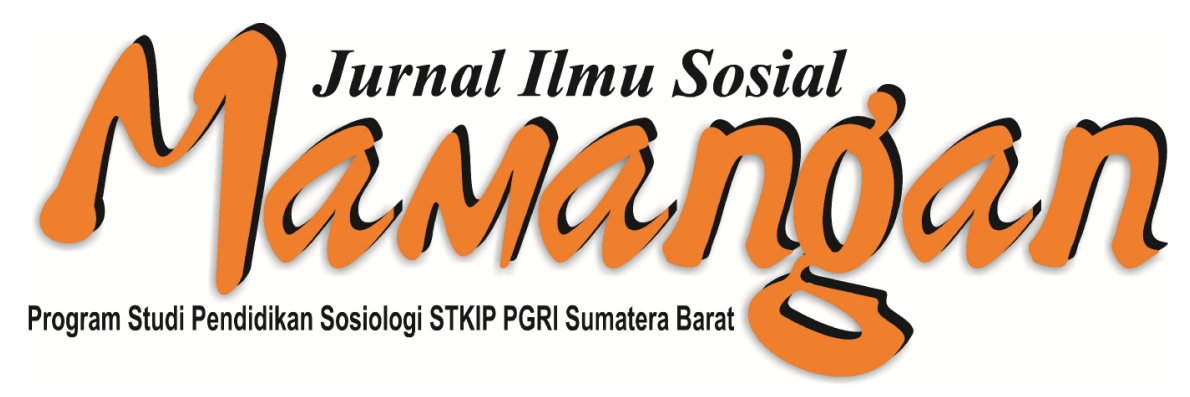

Jurnal Ilmu Sosial Mamangan

Volume 6, Nomor 1, Januari-Juni 2017

Modernisasi Lembaga Pendidikan Pesantren

Penulis : Bashori

Sumber : Jurnal Ilmu Sosial Mamangan, Volume 6, Nomor 1, Januari-Juni 2017

Diterbitkan Oleh : Laboratorium Pendidikan Sosiologi, STKIP PGRI Sumatera Barat

Untuk Mengutip Artikel ini :

Bashori, 2017. Modernisasi lembaga Pendidikan Pesantren.. Jurnal Ilmu Sosial Mamangan, Volume 6, Nomor 1, Januari-Juni 2017: 47-60.

Copyright (C) 2017, Jurnal Ilmu Sosial Mamangan

ISSN : 2301-8496 (Print), ISSN : 2503-1570 (Online)

Laboratorium Pendidikan Sosiologi STKIP PGRI Sumatera Barat 


\title{
Modernisasi Lembaga Pendidikan Pesantren
}

\author{
Bashori \\ STAI Tuanku Tambusai Pasir Pengaraian, Riau \\ Email : bashoribashori@gmail.com
}

\begin{abstract}
Pesantren is an Islamic institution which has the advantage of both aspects of the scientific tradition as well as the transmission side and the intensity of the Muslims. The rise of globalization has threatened the existence of pesantren, so it appears the idea of modernizing the environment of schools to the challenges of social transformation needs. But many people worry about the idea of modernization-oriented pesantren of the present can affect idenitas and primary function of pesantren education institutions. Therefore, it is important we discus and further analyze how the role of the modernization of pesantren education institutions today.
\end{abstract}

Keywords: Institutional Modernization, Institutional of Pesantren Education, Islamic Education.

\begin{abstract}
ABSTRAK
Pesantren merupakan lembaga pendidikan Islam yang memiliki keunggulan baik dari aspek tradisi keilmuannya maupun sisi transmisi dan intensitas umat Islam. Derasnya arus globalisasi telah mengancam eksistensi pesantren sehingga muncul gagasan modernisasi dilingkungan pesantren demi menjawab tantangan kebutuhan transformasi sosial. Akan tetapi banyak kalangan mengkhawatirkan tentang gagasan modernisasi pesantren yang berorientasi kekinian dapat mempengaruhi idenitas dan fungsi pokok lembaga pendidikan pesantren. Oleh karena itu, perlu kiranya kita membahas dan menganalisis lebih jauh bagaimana peranan modernisasi lembaga pendidikan pesantren saat ini.
\end{abstract}

Kata Kunci: Modernisasi Lembaga, Lembaga Pendidikan Pesantren, Pendidikan Islam.

\section{PENDAHULUAN}

Pesantren

merupakan

lembaga pendidikan Islam yang memiliki akar historis yang cukup kuat sehingga menduduki posisi relatif sentral dalam dunia keilmuan. Dalam masyarakatnya, pesantren sebagai sub kultur lahir dan berkembang seiring dengan perubahan-perubahan dalam masyarakat global. Selain itu, salah satu lembaga pendidikan yang mempunyai kekhasan tersendiri dan berbeda dengan lembaga pendidikan yang lainnya (Firdaus \& Wekke, 2017). Ditinjau dari segi historisnya, pesantren merupakan bentuk lembaga pribumi tertua di Indonesia. Lembaga pendidikan pesantren sudah dikenal jauh sebelum Indonesia merdeka, bahkan sejak Islam masuk ke Indonesia, pesantren terus berkembang sesuai dengan perkembangan dunia pendidikan pada umumnya.

Pesantren sebagai komunitas yaitu sekelompok identitas yang memiliki 
karakteristik organisme sosial dan juga sebagai lembaga pendidikan yang besar jumlahnya dan luas penyebarannya di berbagai plosok tanah air telah banyak memberikan peran dalam membentuk manusia Indonesia yang religius. Lembaga tersebut telah melahirkan banyak kepemimpinan bangsa Indonesia dimasa lalu, kini dan agaknya juga dimasa yang akan datang, selain lulusan pesantren telah memberikan partisipasi aktif dalam pembangunan bangsa.

Peran pesantren dimasa lalu kelihatannya paling menonjol dalam hal menggerakkan, memimpin dan melakukan perjuangan dalam rangka mengusir penjajah. Di masa sekarang, juga amat jelas ketika pemerintah mensosialisasikan programnya dengan melalui pemimpin-pemimpin pesantren. Pada masa-masa mendatang agaknya peran pesantren amat besar misalnya, arus globalisasi dan industrialisasi telah menimbulkan depresi dan bimbanganya pemikiran serta suramnya prespektif masa depan, maka pesantren sangat dibutuhkan untuk menyeimbangakan akal dan hati (Tafsir, 2011).

Di kalangan umat Islam sendiri nampaknya pesantren telah dianggap sebagai model institusi pendidikan yang memiliki keunggulan baik dari aspek tradisi keilmuannya yang merupakan salah satu tradisi agung maupun sisi transmisi dan internalisasi moralitas umat Islam. Malik Fajar (1998) menegaskan bahwa, Dalam sejarah pertumbuhan dan perkembangan pendidikan Islam di Indonesia tidak dipungkiri bahwa pesantren telah menjadi semacam local genius (Fajar, 2010). Hal tersebut menunjukkan bahwa peran pesantren telah merambah ke segala bidang bahkan telah menjadi bagian dari sistem pendidikan nasional kita, maka sangat keliru jika ada anggapan bahwa peran pesantren sangat kecil dan rendah dalam mensukseskan program pembangunan nasional.

Untuk mempertegas pentingnya peranan lembaga pendidikan pesantren di Indonesia, kehadiran pesantren selain dikatakan penting dalam tatanan kehidupan sosial juga dapat dikatakan sebagai hal yang unik. Dapat dikatakan unik karena dua alasan yakni pertama, pesantren hadir untuk merespon terhadap situasi dan kondisi suatu masyarakat yang dihadapkan pada runtuhnya sendi-sendi moral atau bisa disebut perubahan sosial. Kedua, didirikannya pesantren adalah untuk menyebar luaskan ajaran universalitas Islam ke seluruh pelosok nusantara (Wahid \& Zuhri, 1999).

Dalam perkembanganya, lembaga penddikan pesantren melalui berbagai siklus perkembangannya baik dalam tatanan metodologi maupun keorganisasian pesantren itu sendiri. Lebih lagi perihal modernisasi kelembagaan yang merupakan kata yang identik dengan perkembangan pesantren saat ini. Modernisasi menjadi kecenderungan umum dalam semua aspek kehidupan baik politik, ekonomi, sosial, pendidikan, dan bahkan agama.

Salah satu aspek yang jelas terlihat adalah dalam dunia pendidikan, sebagai aspek yang erat kaitannya dengan modernisasi. Adanya gagasan untuk mengembangkan lembaga pesantren merupakan pengaruh program modernisasi pendidikan Islam. Program modernisasi tersebut berakar pada modernisasi pemikiran dan institusi Islam secara keseluruhan. Modernisasi pendidikan Islam tidak dapat dipisahkan dengan kebangkitan kaum muslimin di masa modern. Oleh sebab itu, pemikiran dan kelembagan Islam termasuk pendidikan (pesantren) haruslah dimodernisasi yaitu diperbaharui sesuai dengan kerangka modernitas. Dengan kata lain, mempertahankan pemikiran kelembagaan Islam tradisional akan memperpanjang nestapa ketertinggalan umat Islam dalam kemajuan dunia modern. Hal ini memunculkan pertanyaan bagi Azra "bagaimana sesungguhnya hubungan antara modernisasi dan pendidikan, lebih khusus dengan pendidikan Islam di Indonesia?" (Azra, 2000)

Masyarakat dunia kini semakin terhubung dengan mudah sebagai hasil dari berjalannya proses globalisasi. Sebagai contoh ialah semakin cepat dan masifnya informasi tersebar ke berbagai belahan dunia. Selain masifnya informasi, globalisasi juga berlangsung dalam berbagai lini kehidupan, seperti bidang budaya, ekonomi, politik (Al Akbar, 2016), termasuk lembaga pendidikan. Dampak dari berlangsungnya globalisasi di berbagai lini tersebut seringkali menimbulkan dampak yang negatif 
khususnya bagi negara-negara berkembang termasuk Indonesia.

Modernisasi dimanapun telah mengubah berbagai tatanan dan lembaga tradisional (pesantren). Salah satu diantaranya adalah semakin pudarnya fungsi lembaga Islam. Pudarnya fungsi lembaga keagamaan tradisional dalam kehidupan modern merupakan penjelas perubahan posisi sosial, ekonomi dan politik elit muslim yang dibangun di atas kekuasaan dan legitimasi keagamaannya. Pemikiran Islam kontemporer merupakan upaya elit muslim memperoleh legitimasi agama atas posisi sosial, ekonomi dan politiknya dalam lembaga sekuler (Mulkhan, 2002).

Perjalanan pendidikan Islam tradisional khususnya pesantren telah begitu panjang. Ketika arus globalisasi telah membawa perkembangan sosial kultur masyarakat yang semakin maju, maka tak heran ketika problem yang dialami pesantren sebagai pendidikan semakin kompleks, sehingga Azra meneliti tentang adanya permasalahan yang dihadapi sistem pemikiran dan pendidikan Islam yaitu pertama, berkenaan dengan situasi riil sistem pemikiran dan sistem pendidikan Islam, yaitu krisis konseptual. Krisis konseptual dimaksudkan tentang bagaimana tepat dan sepatutnya secara epistimologi menjelaskan ilmu- ilmu empiris atau ilmu-ilmu alam dari kerangka epistimologi Islam (Azra, 2000).

Dalam konteks masyarakat muslim Indonesia juga terjadi pemilahan antara Islam tradisionalis dan Islam modernis. Di sini Islam modernis diwakili oleh Muhammadiyah, Persis, dan lain-lain; dengan Islam tradisionalis diwakili oleh $\mathrm{NU}$ dan sebagainya. "Dikotomi tersebut secara struktural telah membawa perubahanperubahan dalam pergerakan Islam selama beberapa dasa warsa akhir-akhir ini" (Azra, 1999). Hal tersebut mengakibatkan bermunculannya konsep-konsep pemahaman yang sangat kompleks.

Permasalahan kedua, yaitu krisis lembaga. Krisis lembaga ini adanya dikotomisasi antara lembaga-lembaga pendidikan yang menekankan pada salah satu ilmu saja apakah itu ilmu agama atau ilmu umum. Menurut Azyumardi Azra (1998), "pengintegrasian antara ilmu umum dengan ilmu agama dalam upaya rekonstruksi ilmu harus melalui perumusan yang jelas, yaitu bagaimana ilmu-ilmu eksakta diajarkan dalam kerangka Islami. Bagaimana memberikan warna Islam terhadap ilmu-ilmu yang bersifat umum",

Sejalan dengan Nurcholis Madjid yang menyatakan bahwa bagaimana menempatkan kembali ilmu pengetahuan dan teknologi ke dalam daerah pengawasan nilai agama, moral dan etika (Yasmadi, 2002). Karena pada prinsipnya asal mula semua cabang ilmu pengetahuan adalah berpangkal pada ilmu agama. Pada masa Islam klasik, para intelektual Islam mampu mengembangkan dan mengislamkan ilmu pengetahuan modern. Misalkan ada nama ilmu pengetahuan dan teknologi modern Barat berasal dari bahasa Islam. Hal itu disebabkan para intelektual muslim pada masa Islam klasik hanya lahir dari satu lembaga yaitu madrasah atau pesantren tanpa ada pemilahan madrasah yang umum atau agama.

Persoalan ketiga yaitu krisis metodologi. Kecenderungan lembaga-lembaga pendidikan Islam lebih merupakan proses teaching, proses pengajaran ketimbang proses learning, proses pendidikan. "Pengajaran hanya mengedepankan aspek kognitif, tetapi tidak mengisi aspek pembentukan pribadi dan watak" (Azra, 1999). Penggunaan metode pendidikan Islam adalah bagaimana seorang pendidik dapat memahami hakikat metode dan relevansinya dengan tujuan utama pendidikan Islam, yaitu terbentuknya pribadi yang beriman yang senantiasa siap sedia mengabdi kepada Allah SWT dan bagaimana pendidik dapat mendorong anak didiknya menggunakan akal pikirannya dalam mempelajari kehidupannya dan alam sekitar (Muhaimin, 1993).

Meninjau kembali pentingnya peranan modernisasi dalam lembaga pendidikan Islam; khususnya pondok pesantren yang selalu mengalami perubahan, baik dalam aspek kurikulum, pembelajaran, kepemimpinan, manajerial, media, dan lainnya. Dengan demikian, tulisan ini memotret peranan modernisasi pada satu sisi, sedangkan pada sisi lain tulisan ini mengaitkan keniscayaan dan sekaligus kekhawatiran modernisasi dalam lembaga pendiidkan Islam, yaitu bagaimana modernisasi di pesantren tersebut tetap mampu menjaga identitas pesantren. Sehingga tulisan ini mampu memberikan 
pemahaman tentang modernisasi pendidikan Islam, terutama dalam konteks pendidikan di pesantren.

\section{METODE PENELITIAN}

Penelitian ini merupakan penelitian kepustakaan (library research), yaitu penelitian yang fokus penelitiannya menggunakan data dan informasi dengan bantuan berbagai macam material yang terdapat di ruang perpustakaan, seperti: buku-buku, majalah, naskah-naskah, catatan, kisah sejarah, dokumen-dokumen, dan lainlain (Kartini, 1996).

Dalam pengumpulan data, penulis menggunakan metode kualitatif sebagai prosedur penelitian yang dapat menghasilkan data deskriptif berupa kata-kata tertulis atau kuasa verbal dari objek penelitian (Meleong, 2000). Karena penelitian ini merupakan penelitian kepustakaan, maka dalam mengumpulkan data, penulis membagi sumber data menjadi dua bagian: 1) Sumber data primer, yaitu karya buku-buku karya Azyumardi Azra yang membahasa tentang pendidikan Islam khususnya pendidikan pesantren. 2). Sumber data sekunder, mencakup referensi-referensi lain yang ditulis oleh para intelektual lainnya sebagai bahan pijakan dan tolak ukur dalam menganalisis gagasan dan pemikiran Arief Furchan atau review dan telaah terhadap karyanya.

Selanjutnya pengolahan data dalam penelitian ini menggunakan metode deskriptif-analitis, yaitu model penelitian yang berupaya mendeskripsikan, mencatat, menganalisa dan menginterpretasikan kondisi-kondisi yang ada (Mardalis, 1996). Dalam hal ini, penulis akan berusaha mendeskripsikan secara sistematis gagasan dan pemikiran tentang modernisasi lembaga pendidikan Islam di Indonesia. Kemudian penulis akan mencoba menganalisa pemikirannya baik dalam kerangka teoritis atau dalam dimensi praksis.

Sebagai alat untuk menganalisis (tool of analysis) data, penulis memakai hermeneutika sosial kritis. Ini dimaksudkan untuk menganalisa secara jernih makna yang terkandung dalam keseluruhan gagasan dan pemikiran tentang modernisasi pendidikan Islam di Indonesia. Analisa ini berupaya menembus apa yang ada di balik fungsi permukaan pemikiran, sehingga akan tersingkap perannya sebagai instrumeninstrumen politik, dominasi, dan manipulasi sosial. Pada akhirnya alat semacam kritik dalam hal ini mencoba menguji sahih tidaknya klaim-klaim pengetahuan tanpa prasangka dengan menggunakan rasio (Hardiman, 1993). Kritik akan sangat membantu untuk mengetahui lebih detail kepentingan-kepentingan yang menyertai pemikiran dan gagasannya.

\section{GAMBARAN UMUM PESANTREN}

Dalam tinjauan historis tentang pesantren masih dibatasi pada persoalan sejarah pertumbuhan serta gambaran secara umum mengenai pesantren itu sendiri. Hal ini karena berkaitan dengan sulitnya mencari data-data sejarah tentang awal berdirinya pesantren. Dalam buku-buku yang berkaitan dengan sejarah pesantren belum mampu menyimpulkan kapan berdirinya pesantren. Bidang kajian dari penulis-penulis tersebut, hanya masih taraf penemuan-penemuan hubungan kebudayaan melalui matrik kurikulum, tradisi serta simbol-simbol bahasa yang sering dipakai dalam dunia pesantren. Seperti dalam tulisan Karel A. Steenbrink, model pendiskripsinya masih bermuara pada seputar hubungan pesantren dengan warisan Hindu-Budha, atau juga hubungan pesantren dengan tradisi kebangkitan Islam abad pertengahan di Timur-Tengah (Steenbrink, 1989).

Pesantren sebagai lembaga pendidikan dan pusat penyebaran agama Islam lahir dan berkembang semenjak masa-masa permulaan Islam masuk di Indonesia. Di pulau Jawa lembaga ini berdiri untuk pertama kalinya di zaman walisongo. Untuk sementara, Sheikh Malik Ibrahim atau yang disebut Sheikh Maghribi dianggap sebagai ulama yang pertama kali mendirikan pesantren di Jawa (Kafrawi, 1978). Anggapan demikian bisa dimengerti, karena melihat kondisi obyektif pesantren dengan segala elemen dan tata cara serta kebahasaanya, dimana di dalamnya terdapat elemen HinduBudha dan Islam. Misalnya Istilah funduq berasal dari bahasa Arab, yang artinya pesangrahan atau penginapan bagi orang yang berpergian. Sedangkan istilah pesantren berasal dari kata santri atau sangsekertanya adalah shantri yang berarti ilmuwan Hindu 
yang pandai menulis (Wahyoetomo,1997). Menurut Kafrawi (1978), hal itulah yang kemudian dimiliki oleh Sheikh Maghribi. Sebagai seorang ulama yang dilahirkan di Gujarat India, yang sebelumnya telah mengenal perguruan Hindu-Budha dengan sistem biara dan asrama sebagai proses belajar mengajar para biksu dan pendeta. Sistem pesantren menyerupai itu, hanya terjadi perubahan dari pengajaran agama Hindu dan Budha kemudian menjadi pengajaran agama Islam.

Seperti halnya yang pernah dirintis oleh para wali, dalam fase selanjutnya, berdirinya Pondok Pesantren tidak bisa lepas dari kehadiran seorang kyai. Kyai tersebut biasanya sudah pernah bermukim bertahuntahun bahkan berpuluh-puluh tahun untuk mengaji dan mendalami pengetahuan agama Islam di Makkah atau di Madinah, atau pernah mengaji pada seorang kyai terkenal di tanah air, lalu menguasai beberapa atau satu keahlian (fak) tertentu.

Kondisi lain yang tergambar dalam kehidupan kyai, juga sisi kehidupan kyai yang bermukim di sebuah desa. Langkah awal kyai untuk membangun lembaga pendidikan Islam, adalah dengan mendirikan langgar atau surau untuk sholat berjamaah, biasanya diikuti oleh sebagian masyarakat desa. Pada setiap menjelang atau selesai sholat, kyai mengadakan pengajian agama, yang materi pengajiannya meliputi rukun Iman, rukun Islam dan akhlaq (Dhofier, 1982).

Dalam beberapa literatur, istilah pondok secara bahasa yaitu pondok pesantren berasal dari dua kata "pondok" dan "pesantren". Pondok berarti asrama-asrama para santri yang dibuat dari bambu, atau berasal dari kata Arab funduq, yang berarti rumah penginapan, hotel atau asrama. Sementara itu, pesantren berakar pada kata "santri" yang berasal dari bahasa Sanskerta yang berarti melek huruf, yaitu orang yang berusaha mendalami kitab-kitab yang ditulis dalam bahasa Arab (Mun'im, 2009).

Pengertian tersebut memberikan isyarat bahwa pesantren dalam menyelenggarakan proses pendidikan menyediakan asrama untuk para santri atau peserta didiknya. Namun bukan berarti setiap lembaga pendidikan yang menyiapkan asrama bagi peserta didik itu dikategorikan sebagai pondok pesantren, sebab pada zaman sekarang, beberapa sekolah sudah memilikinya, bahkan telah terpenuhi segala fasilitas yang mendukungnya.

Selain itu, M. Dawam Raharjo mengemukakan bahwa pesantren adalah suatu lembaga keagamaan yang mengajarkan, mengembangkan dan menyebarkan ilmu agama Islam. Meskipun pesantren sebagai pranata Islam tradisional, pesantren dapat berperan aktif dalam perjuangan melawan keadilan social ekonomi, dan kebudayaan (Sholihah, 2012).

Dari deskripsi di atas, dapat disimpulkan bahwa pesantren adalah lembaga pendidikan keagamaan Islam berbasis masyarakat yang menyelenggarakan pendidikan diniyah (tradisional) atau secara terpadu dengan jenis pendidikan lainnya, seperti pendidikan formal (modern). Dari pengertian tersebut juga dapat ditarik kesimpulan bahwa pondok pesantren terdiri dari beberapa unsur, yakni: unsur Kyai, santri, ustadz dan asrama, serta pendidikan yang dikembangkan ditekankan pada pendidikan moral keagamaan. Sehingga pondok pesantren adalah lembaga pendidikan Islam yang mengajarkan disiplin ilmu keagamaan dalam satu asrama. Islam tidak pernah menganak tirikan pengetahuan umum, namun yang paling menonjol dalam pendidikan di pondok pesantren adalah pendidikan moral keagamaan.

\section{TIPOLOGI PESANTREN}

Secara garis besar, lembaga pesantren di Jawa Timur dapat digolongkan menjadi dua kelompok besar yaitu: 1) Pesantren Salafi: yaitu pesantren yang tetap mempertahankan sistem (materi pengajaran) yang sumbernya kitab-kitab klasik Islam atau kitab dengan huruf Arab gundul (tanpa baris apapun). Sistem sorogan (individual) menjadi sendi utama yang diterapkan. Pengetahuan non agama tidak diajarkan; dan 2) Pesantren Khalafi: yaitu sistem pesantren yang menerapkan sistem madrasah yaitu pengajaran secara klasikal, dan memasukan pengetahuan umum dan bahasa non Arab dalam kurikulum (Departemen Agama, 2003).

Menurut Mukti Ali dalam Pembangunan Pendidikan dalam Pandangan Islam, sistem pengajaran di Pondok Pesantren dalam garis besarnya ada beberapa macam yaitu: a) Sistem Wetonan, pada sistem ini Kiai membaca suatu kitab dalam waktu tertentu, dan santri dengan membawa kitab yang sama 
mendengarkan dan menyimak bacaan kiai tersebut. Dalam sistem pengajaran yang semacam ini tidak mengenal absen. Santri boleh boleh datang dan tidak boleh datang, juga tidak ada ujian. Apakah santri itu memahami apa yang dibaca Kiai atau tidak, hal itu tidak bisa diketahui. Dalam hal ini dapat dikatakan bahwa sistem pengajaran di Pondok Pesntren itu adalah bebas, yaitu bebas mengikuti kegiatan belajar dan bebas untuk tidak mengikuti kegiatan belajar; b) Sistem Sorogan, pada sistem ini santri (biasanya yang pandai) menyedorkan sebuah kitab kepada kyai untuk dibaca di hadapan kiai itu. Kalau ada kesalahan langsung dibetulkan oleh kiai itu. Di Pondok Pesantren yang besar, mungkin untuk dapat tampil di depan kiainya dalam membawakan/ menyajikan materi yang ingin disampaikan, dengan demikian santri akan dapat memahami dengan cepat terhadap suatu topik yang telah ada pada kitab yang dipegangnya; c) Metode Muhawarah, yaitu suatu kegiatan berlatih bercakap-cakap (conversation) dengan Bahasa Arab yang diwajibkan oleh pimpinan pesantren kepada santri selama mereka tinggal di pondok; d) Metode Mudzakarah, Mudzakarah merupakan suatu pertemuan ilmiah yang secara spesfik membahas masalah diniyah seperti ibadah dan akidah serta masalah agama pada umumnya. Metode ini biasanya digunakan santri untuk menguji ketrampilannya baik dalam Bahasa Arab maupun mengutip sumber-sumber argumentasi dalam kitabkitab Islam klasik. Dalam metode ini, secara tidak langsung santri diuji kemampuan beragumentasi sekaligus sampai sejauh mana materi maupun referensi yang dimilikinya dengan keluasan wawasan yang ada; dan e) Metode Majelis Ta'lim, Majelis Ta'lim adalah media penyampaian ajaran Islam yang bersifat umum dan terbuka. Para jama'ah terdiri dari berbagai lapisan yang memiliki latar belakang pengetahuan bermacammacam dan tidak dibatasi oleh tingkatan usia maupun perbedaan kelamin. Pengajian semacam ini hanya diadakan pada waktuwaktu tertentu saja.

Kelima metode tersebut $\mathrm{di}$ atas dikategorikan ke dalam sistem pendidikan non klasikal. Selain sistem pendidikan non klasikal ini, pesantren juga menerapkan sistem pendidikan klasikal. Untuk sistem pendidikan yang kedua ini hanya dipakai oleh pesantren pesantren modern.

Sedangkan metode dari sistem klasikal ini, menurut Dawam Raharjo dapat berupa: metode ceramah, metode kelompok, metode tanya jawab dan diskusi, dan metode dramatisasi (Rahardjo, 1982). Membahas lebih lanjut mengenai pesantren, hasil penelitian Arifin di Bogor menunjukkan adanya lima macam pola fisik pondok pesantren, yaitu: Pola Pertama: Terdiri dari Masjid dan rumah Kyai, pondok pesantren ini masih berifat sederhana, dimana Kiai mempergunakan Masjid atau rumahnya sendiri sebagai sarana untuk tempat interaksi belajar mengajar. Dalam pola semacam ini, santri hanya datang dari daerah sekitar pondok pesantren itu sendiri, sehingga tidak diperlukannya sarana untuk bermukim bagi santri; Pola kedua: Pada pola berikut ini terdiri dari Masjid, rumah Kiai dan pondok (asrama) sebagai tempat menginap para santri yang datang dari jauh. Sehingga tidak mengganggu mereka dalam menuntut ilmu pada Kiai tersebut; Pola ketiga: Terdiri dari Masjid, rumah kiai dan pondok dengan sistem wetonan dan sorogan. Pada pondok pesantren yang merupakan tipe ini telah menyelenggarakan pendidikan formal seperti madrasah sebagai sarana penunjang bagi pengembangan wawasan para santri; Pola keempat: Untuk pola ini, pondok pesantren selain memiliki, komponan-komponen fisik seperti pola ketiga, memiliki pula tempat untuk pendidikan keterampilan seperti kerajinan, perbengkelan, toko, koperasi, sawah ladang dan sebagainya. Sehingga sebagai sarana edukatif lainnya sebagai penunjang memiliki nilai lebih dibanding dengan pola ketiga; dan Pola kelima: Dalam pola yang terakhir ini pondok pesantren telah berkembang dengan pesatnya sesuai dengan perkembangan zaman dan yang lazim disebut dengan pondok pesantren modern atau pondok pesantren pembanunan. Disamping Masjid, rumah kyai/ustadz, pondok, madrasah dan atau sekolah umum, terdapat pula bangunan-bangunan fisik lainnya sebagai penunjang seperti; perpustakaan, dapur umum, rumah makan umum, kantor administrasi, toko/unit usaha, koperasi rumah penginapan tamu, ruang operasi dan sebagainya (Kartini, 1996). 


\section{MODERNISASI PESANTREN}

Istilah modern berasal dari Bahasa Latin akhir abad kelima masehi, yaitu modernus, yang digunakan untuk membedakan keadaan orang Kristen dengan orang Rowawi dari masa pagan yang telah lewat. Sesudah itu, istilah tersebut digunakan untuk menempatkan keadaan masa kini dalam kaitannya dengan berlalunya zaman purbakala, yang sering muncul kembali selama periode tersebut di Eropa. Dalam hubungannya dengan akal, agama dan apresiasi estetik, dinyatakan bahwa zaman modern merupakan zaman yang lebih maju, lebih baik dan memiliki kebenaran yang lebih banyak dari pada zaman kuno (zaman sebelumnya). Peter Sztompka menyatakan bahwa modernisasi merupakan proses perubahan sistem sosial, ekonomi dan politik yang telah maju di Eropa Barat dan Amerika dari abad ketujuh belas hingga kesembilan belas, dan kemudian menyebar ke negaranegara lain, seperti Amerika Selatan, Asia dan Afrika dari abad ke-19 hingga ke-20 (Solichin, 2014).

Menghadapi perubahan zaman yang begitu cepat, dunia pesantren mengalami pergeseran ke arah perkembangan yang lebih positif, baik secara struktural maupun kultural, yang menyangkut pola kepemimpinan, pola hubungan pimpinan dan santri, pola komunikasi, cara pengambilan keputusan dan sebagainya, yang lebih memperhatikan prinsip-prinsip manajemen ilmiah dengan landasan nilai-nilai Islam. Dinamika perkembangan pesantren semacam inilah yang menampilkan sosok pesantren yang dinamis, kreatif, produktif dan efektif serta inovatif dalam setiap langkah yang ditawarkan dan dikembangkannya. Sehingga pesantren merupakan lembaga yang adaptif dan antisipatif terhadap perubahan dan kemajuan zaman dan teknologi tanpa meninggalkan nilai-nilai relegius.

Dalam hal kepengurusan pesantren, menurut Abdurrahman Wachid, kepengurusan pesantren adakalanya berbentuk sederhana, dimana kyai memegang pimpinan mutlak dalam segala hal, sedangkan kepemimpinannya itu seringkali diwakilkan kepada seorang ustadz senior selaku "lurah pondok". Dalam pesantren yang telah mengenal bentuk organisatoris yang komplek, peranan "lurah pondok" ini digantikan oleh susunan pengurus lengkap dengan pembagian tugas masing-masing, walaupun ketuanya masih dinamai lurah juga.

Dari aspek sistem banyak pesantren yang menggunakan sistem klasikal, dengan metodologi yang disesuaikan dengan metode pengajaran moderen, yaitu; metode ceramah, metode kelompok, metode tanya jawab dan diskusi, metode demonstrasi dan eksperimen, metode dramatisasi. Dalam hal pengembangan materi pembelajaran, pesantren modern tidak hanya mematok kitab tertentu sebagaimana pesantren lama, namun sudah mengembangkan materi dalam bentuk kurikulum dengan muatan yang lebih komprehensif.

Kecuali dari sudut pandang fisikal, kemajuan yang telah berkembang dalam dunia pesantren juga dapat dipandang dari sudut-sudut pandang lain, antara lain, dari segi kelembagaan, kurikulum, dan metode pembelajarannnya. Semua hal itu tentu memiliki konsekuensi logis yang perlu dan harus dipertimbangka dalam setiap melakukan modernisasi lembaga pendidikan Islam.

\section{MODERNISASI LEMBAGA PENDIDIKAN PESANTREN \\ Modernisasi Kelembagaan}

Sejak Belanda mendirikan lembaga pendidikan umum, sekolah rakyat atau sekolah Desa dengan masa belajar selama 3 tahun di beberapa tempat di Indonesia pada tahun 1870-an telah mempengaruhi lembaga pendidikan Islam, Perkembangan selanjutnya tradisi baru pendidikan itu menjadi inkulturalisasi terhadap tradisi Asli pesantren atau surau. Banyak pesantren atau surau melakukan perubahan. Misalnya memasukkan mata pelajaran umum. Tidak hanya itu saja, ada pesantren atau surau berubah menjadi madrasah dan berubah dari fungsi aslinya.

Dalam masa-masa kesulitan ekonomi yang terjadi di Indonesia pada dekade 1950an dan awal 1960-an, pembaharuan pesantren banyak berkenaan dengan pemberian ketrampilan khususnya dalam bidang pertanian. Santri diharapkan mempunyai bekal dan untuk mendukung ekonomi pesantren. Azyumardi Azra melihat: "Adanya tuntutan kepada pesantren untuk self supporting dan self financing." Karena pada saat itu terjadi krisis ekonomi sehingga 
banyak pesantren di pedesaan seperti Tebuireng dan Rejoso, mengarahkan pada santrinya untuk terlibat dalam kegiatankegiatan vacational dalam bidang pertanian seperti penanaman padi, kelapa, tembakau, kopi dan lainnya. Hasil penjualan dari usaha pertanian seperti itu digunakan untuk membiayai pesantren (Azra, 1998).

Setelah pesantren dan sistem kelembagaan madrasah modern berada di bawah tanggung jawab dan pengawasan Departemen Agama maka banyak pesantren yang mendirikan madrasah.

Pesantren mengalami perubahan yang sangat signifikan karena berlangsungnya modernisasi pesantren di Jawa sejak masa orde baru. Dalam perubahan-perubahan itu, pesantren kini memiliki empat jenis pendidikan. "Pertama, pendidikan yang berkonsentrasi pada tafaqquh fi al-din, kedua, pendidikan berbasis madrasah, ketiga, pendidikan berbasis sekolah umum dan keempat, pendidikan berbasis ketrampilan" (Azra, 2003).

Di antara pesantren-pesantren yang dipandang sebagai perintis dalam Eksperimen ini adalah pesantren Darul Ulum, Rejoso,Peterongan, Jombang, yang pada September 1965 mendirikan Unversitas Darul Ulum, yang terdaftar pada departemen $\mathrm{P} \& \mathrm{~K}$. Universitas ini terdiri dari lima fakultas dan hanya satu fakultas Agama Islam. Pesantren lain yang juga menempuh cara ini adalah pesantren Miftahul mu'alimin di Babakan, Ciwaringin, Jawa Barat, yang mendrikan sebuah STM (Azra, 2003).

Pendidikan merupakan suatu lembaga sosial dalam membentuk individu dalam bersosialisasi untuk meningkatkan harkat martabat manusia. Pendidikan merupakan tanggung jawab masyarakat sebagai orang tua dan pemerintah, maka itu pendidikan perlu menyesuaikan dengan tuntutan pembangunan yang memerlukan berbagai jenis keterampilan dari berbagai bidang (Tapondhadhai, Ansofino, \& Nazmi, 2012). Selain itu, perubahan pesantren tersebut merupakan salah satu respons terhadap perubahan modernisasi yang lebih dahulu dikembangkan oleh Muhammadiyah. Maka pesantren mengadakan pembaharuan dan perubahan yang cukup mendasar. Perubahan tersebut tidak hanya bidang kurikulum saja, tetapi juga menyangkut kelembagaan. Sehingga menimbulkan kekhawatiran yang cukup intens dikalangan pesantren tentang identitas dan jati diri lembaga tersebut.

Kekhawatiran tersebut diungkapkan Azra menyangkut identitas atau distingsi Islam pada madrasah-madrasah yang banyak didirikan di lingkungan pesantren. Karena sesuai dengan UUSPN 1989 madrasah telah dijadikan equivalen atau sama dengan sekolah-sekolah umum. Menurut Azra (1999), "Di mana identitas dan distingsi Islamnya ?".

Sebenarnya persoalan yang kemudian timbul dari perubahan madrasah yaitu menyangkut pembedaan antara lembaga umum dan lembaga agama, ketika madrasah dijadikan sekolah umum atau sama dengan sekolah umum maka sulit bagi kita menyebutkan mana yang berorientasi pada ilmu agama atau mengajarkan ilmu agama? karena madrasah sekarang diharuskan mengikuti program-program pengajaran yang sama dengan sekolah umum dari pemerintah. Hal ini madrasah menjadi tidak independent.

Identitas Islam dalam madrasah tersebut menurut Azra (1999), "Tidak memadai jika hanya terletak pada guru-guru yang memulai pelajaran mengucapkan basmalah atau salam". Sekarang ini di SMA atau sekolah umum mengucapkan salam atau membaca do'a serta basmalah sering digunakan guru dalam mengajar apa saja. Hal ini karena mayoritas guru-guru yang mengajar di SMA beragama Islam. Bahkan guru Kristen saja sudah biasa mengucapkan salam.

Modernisasi pesantren telah banyak mengubah sistem dan kelembagaan pendidikan pesantren. Perubahan yang sangat mendasar misalnya terjadi pada aspek-aspek tertentu dalam kelembagaan. Dalam hal ini, "Banyak pesantren tidak hanya mengembangkan madrasah sesuai dengan pola Departemen Agama, tetapi juga bahkan mendirikan sekolah-sekolah umum dan universitas umum" (Azra, 2003).

Oleh sebab itu, ketidakjelasan mengenai konsep tersebut sangat tidak cocok bila diharapkan dalam pesantren yang sudah memiliki identitas dan fungsi utamanya. Bila hal tersebut dipaksakan, maka akan menimbulkan permasalahan baru yang lebih komplek. Bagi Azra (2003), hal tersebut tidak berarti pesantren tidak peduli dengan perkembangan di luar dunianya. Menurutnya, "Pesantren harus menumbuhkan apresiasi 
yang sepatutnya terhadap semua perkembangan yang terjadi di masa kini dan mendatang, sehingga dapat mereproduksi ulama yang berwawasan luas."

Lahirnya seorang ulama merupakan tugas dari pesantren. Ulama tidak mungkin lahir dari lembaga lain misalnya IAIN, lebihlebih universitas. Karena kebanyakan alumni dari IAIN, lebih-lebih universitas cenderung berpandangan sekuler dan kurang berpengaruh atau tidak mendapat citra di mata masyarakat. Azra (2003) menambahkan: "Ulama keluaran IAIN kebanyakan tidak atau kurang mempunyai kedekatan dengan massa muslim pada tingkatan bawah. Sebagian besar mereka berada di lingkungan birokrasi daripada menjadi ulama yang independen."

Oleh karena itu, tidak usah dipaksakan untuk mengadakan pesantren pertanian, peternakan, perikanan, agro industri dan sebagainya. Bila hal itu terjadi, hanya akan menambah keruwetan. Serahkan kesemuanya pada IAIN dan yang lain. Biarkan pesantren sebagaimana fungsinya dan harus independen tanpa ada intervensi dari pemerintah, serta memberikan pelayanan keagamaan kepada masyarakat sekitar.

\section{Modernisasi Kurikulum}

Sebenarnya gagasan modernisasi pesantren bertitik tolak dari modernisasi pendidikan Islam yang mempunyai akar-akar dalam gagasan tentang modernisasi pemikiran dan institusi Islam secara keseluruhan yaitu modernisasi pemikiran dan kelembagaan Islam yang merupakan prasyarat bagi kebangkitan kaum muslimin dimasa modern. Karena itu, pemikiran kelembagaan Islam (termasuk pendidikan) harus dimodernisasi sesuai dengan kerangka modernitas (Azra, 2003). Gagasan modernisasi pendidikan Islam diawali oleh Ismail Rozi al-Faruqi yang mencoba merumuskan langkah-langkah Islamisasi sains, yang meliputi: "Penguasaan disiplin ilmu modern, penguasaan warisan Islam, penentuan relevansi Islam dengan sain modern, pencarian sintesa kreatif antara wawasan intelektual Islam dan modern, pengarahan pemikiran Islam untuk mencapai kedekatan kepada Allah" (Ali Maksum, 2003).

Hal ini terjadi pengintegrasian antara ilmu Islam dan ilmu umum (Islamisasi sains). Dalam konteks Indonesia, gagasan modernisasi Islam pada awal abad 20 dengan membentuk lembaga-lembaga pendidikan modern yang menggunakan sistem pendidikan kolonial Belanda. Gagasan ini diprakarsai oleh organisasi modernis seperti Muhammadiyah, Al-Irsyad dan lain-lain.

Eksperimen yang dilakukan oleh Abdullah Ahmad Padang dengan Madrasah Adabiyah, yang kemudian diubah menjadi sekolah Adabiyah (1915). Hanya sedikit ciri atau unsur dalam kurikulum Sekolah (HIS) Adabiyah yang membedakannya dengan sekolah Belanda. Madrasah ini mengadopsi seluruh kurikulum pendidikan Belanda dan hanya menambahkan pelajaran agama 2 (dua) jam sepekan. Hal ini juga terjadi pada Muhammadiyah yang mengadopsi sistem pendidikan Belanda. Madrasah Muhammadiyah membedakan diri dengan sekolah-sekolah Belanda hanya dengan memasukkan pendidikan agama (metode Qur'an) ke dalam kurikulumnya.

Karena itu Azra menyebut madrasah yang dikembangkan Muhammadiyah (Islam modernis),"Sebagai sekolah umum (Belanda) plus, karena tidak menjadikan sistem kelembagaan pendidikan Islam tradisional (surau/pesantren) sebagai porosnya" (Azra, 2003). Madrasah model ini seperti sekolah dasar (SD) yang dikembangkan pemerintah sekarang yang hanya memberikan pelajaran agama 2 (dua) jam dalam seminggu. Dalam hal ini menghilangkan diri dari lembaga pendidikan Islam. Sehingga nilai-nilai agama pada murid (santri) sangat minim dan kering dari spiritual keagamaan.

Kekeringan spiritual tersebut terjadi di wilayah Muhammadiyah (Islam modernis), seperti yang dialami Azra ketika aktif di HMI. "Pengalaman keagamaan dia sejak kecil hingga beranjak dewasa sangat bersahaja, kering, jauh dari pernak-pernik yang mengesankan. Organisasi yang diikuti (HMI) tidak menanamkan pengalaman ibadah ritual" (Azra, 2000). Hal ini menunjukkan pentingnya pendidikan keagamaan dalam menumbuhkan dan menanamkan nilai-nilai spiritual kepada anak didik (murid).

Dalam konteks Pesantren, Azra (2000) menyebutkan respon Pesantren terhadap modernisasi pendidikan Islam di Jawa dilakukan oleh: Pesantren Mambaul Ulum di Surakarta mengambil tempat paling depan dalam merambah bentuk respon pesantren terhadap ekspansi pendidikan Belanda dan 
pendidikan modern Islam. Peantren Mambaul Ulum yang didirikan Susuhunan Pakubuwono ini pada tahun 1906 merupakan perintis dari penerimaan beberapa mata pelajaran Umum dalam pendidikan pesantren. Menurut laporan inspeksi pendidikan belanda pada tahun tersebut, pesantren mambaul ulum telah memasukkan mata pelajaran membaca (tulisan latin), Aljbar, dan berhitung ke dalan kurikulumnya. Respon yang sama tetapi dalam nuansa yang sedikit berbeda terlihat dalam pengalaman Pondok Modern Gontor. Berpijak pada basis sistem dan kelembagaan pesantren, pada 1926 berdirilah Pondok Modern Gontor. Pondok ini selain memasukkan sejumlah mata pelajaran Umum ke dalam kurikulumnya, juga mendorong para santrinya untuk mempelajari Bahasa Inggris (selain bahasa Arab) dan melaksanakan sejumlah kegiatan ekstra kurikulker seperti olahraga, kesenian dan sebagainya.

Apa yang dilakukan beberapa pesantren tersebut adalah agar pesantren tetap terus bertahan dan tetap eksis. "Ini berarti mereka mengikuti jejak kaum modernis. Pesantren melakukan akomodasi dan penyesuaian tertentu tanpa mengorbankan esensi dan halhal lainnya agar eksistensi pesantren tetap dipertahankan" (Azra, 2000). Modernisasi yang dilakukan beberapa pesantren tersebut tidak seperti yang dilakukan dari sekolah umum plus yang dikembangkan dikalangan modernis. Mungkin modernisasi yang dilakukan pesantren mengacu pada pembentukan kreativitas dan daya kritis santri seperti yang semula menggunakan sistem halaqoh dan sorogan yang menekankan aspek kognitif serta memandang santri untuk mandiri, seperti di Gontor. Tetapi adanya opini yang cukup kuat, modernisasi pesantren dilakukan karena adanya ekspansi dari sekolah umum plus, sehingga pesantren memasukkan ilmu-ilmu umum dalam kurikulum pesantren.

Dalam pandangan Azra (1998):

"Pemasukan ilmu umum dalam pelajaran atau kurikulum pesantren banyak permasalahannya. Muncul persoalan tentang bagaimana secara epistemologis untuk menjelaskan ilmu-ilmu empiris atau ilmuilmu alam dari kerangka epistemologi Islam tersebut." Hal ini memang menimbulkan persoalan tersendiri dalam tubuh pesantren yang mengalami modernisasi. Kebanyakan ilmu alam yang mereka (pesantren) masukkan dalam kurikulum tidak mempunyai hubungan dengan Islam. Sebagai contoh Pondok Modern Gontor salah satunya yang memasukkan kurikulum pelajaran umum, bahasa Inggris. Jelas sekali pelajaran bahasa Inggris tidak ada hubungannya dengan tradisi keilmuan dalam Islam. Hal ini beda dengan bahasa Arab yang digunakan untuk mempelajari kitab kuning dalam pesantren tradisional. Bahasa Arab mempunyai hubungan yang erat dengan bahasa Al-Qur'an.

Kalau terus-menerus dilanjutkan, hal ini akan berdampak lain seperti seorang santri yang intens dalam mempelajari bahasa Inggris atau matematika (hitung). Maka akan timbul asumsi atau opini dalam masyarakat tentang pemaknaan santri. Pemaknaan santri sekarang, orang/murid yang menuntut ilmu agama bukannya orang yang mahir berbahasa Inggris atau pandai berhitung. Rasanya tidak mungkin merumuskan Islamisasi sains seperti yang dikatakan Ismail Rozi Al-Faruqi: "Pemilahan tersebut sebenarnya tidak hanya dalam tataran keilmuan, tetapi telah meluas pada sosiologis masyarakat muslim tertentu dengan muncul varian-varian yang mencakup santri abangan dan priyayi. Mereka yang tergolong santri merupakan muslim yang mempraktekkan Islam yang sebenarnya. Sedangkan "abangan" yang hampir seluruhnya memeluk Islam, mereka tidak mengakui bagian dari umat" (Azra, 1999).

"Dikotomi santri-abangan terlanjur populer, bukan hanya dalam dunia keilmuan tetapi juga digunakan untuk menjelaskan pemilahan politik dalam masyarakat Jawa khususnya" (Azra, 2000). Dangan demikian, perbedaan dan pemilahan di atas terjadi secara alami berkembang di masyarakat. Pemaknaan santri sejak dulu hingga sekarang masih sebagai mereka yang intens pada tradisi Islam, bukan sebaliknya.

Melihat pada kurikulum pendidikan pesantren yang lebih berorientasi kepada "kekinian", di lingkungan pesantren menimbulkan berbagai komentar di beberapa pihak termasuk kalangan pesantren sendiri terjadinya kemerosotan identitas pesantren. "Kalau kurikulum yang berorientasi "kekinian" itu terus berlangsung, maka pesantren akan tidak mampu lagi memenuhi fungsi pokoknya, yakni 
menghasilkan manusia-manusia santri dan melakukan reproduksi ulama" (Azra, 1999)

Kekhawatiran tersebut sangat beralasan karena seorang santri dan ulama tidak akan lahir dalam lembaga selain pesantren. Hal ini diungkapkan Azra (1999) bahwa: Pesantren perlu mengkaji ulang secara cermat dan hatihati berbagai gagasan untuk mengorientasikan pesantren pada tantangan kekinian, sebab bukan tidak mungkin orientasi semacam itu akan menimbulkan implikasi dan fungsi pokok pesantren itu sendiri.

Kekhawatiran Azra tersebut cukup beralasan karena gagasan yang dikemukakan Habibie diterapkan dalam pesantren, maka akan mempengaruhi keaslian dan kekhasan pesantren sebagai sub kultur. Maka sudah sepatutnya pesantren merekonstruksi kurikulumnya yaitu mengorientasikan peningkatan kualitas para santrinya pada penguasaan ilmu agama. Dalam ilmu agama, Azra (1999) mengharapkan: “Teologi yang diajarkan dalam pesantren tidak hanya teologi Asy'ariyah atau Jabariah, tetapi teologi yang kondusif bagi pembangunan, yakni teologi yang mendorong bagi tumbuhnya prakarsa, usaha atau etos kerja." Hal ini dilakukan bukannya pesantren tidak tanggap pada perkembangan, tetapi demi menjaga identitasnya. Jangan sampai perubahan tersebut mengorbankan esensi dan hal-hal dasariyah pesantren.

\section{Metodologi Modernisasi}

Pembaharuan pertama, dilakukan Madrasah Adabiyah yang mengadopsi seluruh kurikulum Belanda. Hanya memasukkan pelajaran agama 2 jam dalam sepekan. Selaras dengan itu, Muhammadiyah juga mengadopsi sistem dan kelembagaan pendidikan Belanda secara cukup konsisten dan menyeluruh seperti MULO, HIS, dan lainlain. Muhammadiyah hanya memasukkan pelajaran agama yaitu metode Qur'an ke dalam kurikulumnya. Hal ini juga terjadi di pesantren dengan mengadopsi aspek tertentu dari sistem pendidikan modern, khususnya dalam kandungan kurikulum, teknik dan metode pengajaran dan sebagainya. Misalkan Pondok Modern Gontor Ponorogo melakukan modernisasi sistem dan kelembagaan pendidikan Islam Indigenous, asli Indonesia.

Pesantren Mambaul Ulum di Surakarta mengambil tempat paling depan dalam merambah bentuk respon pesantren terhadap Ekspansi pendidikan Belanda dan pendidikan modern Islam. Pesantren Mambaul Ulum yang didirikan Susuhunan Pakubuwono ini pada tahun 1906 merupakan perintis dari penerimaan beberapa mata pelajaran umum dalam pendidikan pesantren. Menurut laporan inspeksi pendidikan belanda pada tahun tersebut, pesantren mambaul ulum telah memasukkan mata pelajaran membaca (tulisan latin), Aljabar, dan berhitung ke dalan kurikukulmnya. Respon yang sama tetapi dalam nuansa yang sedikit berbeda terlihat dalam pengalaman Pondok Modern Gontor. Berpijak pada basis sistem dan kelembagaan pesantren, pada 1926 berdirilah Pondok Modern Gontor. Pondok ini selain memasukkan sejumlah mata pelajaran umum ke dalam kurikulumnya, juga mendorong para santrinya untuk mempelajari Bahasa Inggris (selain bahasa Arab) dan melaksanakan sejumlah kegiatan ekstra kurikulker seperti olahraga, kesenian dan sebagainya (Azra, 1999).

Modernisasi pesantren menemukan momentumnya sejak akhir 1970-an dengan mengubah sistem dan kelembagaan pendidikan pesantren. Lebih-lebih banyak pesantren tidak hanya mengembangkan madrasah sesuai dengan pola Departemen Agama, tetapi juga mendirikan sekolahsekolah umum dan universitas umum (Azra, 1999).

Dalam pengamatan Abdul Munir Mulkhan penggabungan kedua ilmu (ilmu agama dan ilmu umum) dengan sistem kebenaran dan metodologi berbeda sebagai akibat modernisasi, justru bisa menumbuhkan sikap ambivalen peserta didik dan bisa mengganggu perkembangan jiwanya. Dia menambahkan, penggabungan ilmu dalam sistem kurikulum pesantren modern telah menyebabkan peserta didik keberatan beban dari yang seharusnya bisa mereka pikul. Akibat lebih lanjut ialah pengembangan kemampuan peserta didik dalam menguasai ilmu yang terkesan lambat dan hasil belajar yang cenderung rendah (Mulkhan, 2002).

Sehingga tidak heran pesantrenpesantren tersebut semakin formalis dengan sistem pengajarannya kepada santri. Adanya kurikulum yang ketat dan sistem perjenjangan telah merubah metode yang 
khas dalam pesantren. Di sini santri dituntut aktif dan kreatif. Lebih jauh lagi pesantren mengikuti program pemerintah yang sangat formal akademis. Di sini juga santri dijadikan seperti barang yang siap untuk diproduksi untuk menjadi ini dan itu.

Sekarang sistem pendidikan Islam menurut Azra (1998): "Semakin sangat formal pendidikannya, hanya menekankan aspek pengajaran. Sementara aspek learningnya, aspek pembentukan kepribadiannya terabaikan." Sistem yang dikembangkan pesantren modern telah menekankan pada penguasaan materi pelajaran. Karena adanya waktu dan tingkatan yang terbatas dalam proses belajar mengajar.

Kecenderungan sistem pengajaran yang berorientasi pada ranah kognitif terlihat pada gagasan Habibie dan kalangan ICMI yang mengembangkan pesantren sekaligus sebagai wahana untuk menanamkan apresiasi dan bahkan bibit-bibit keahlian dalam bidang sains-teknologi.

Disini pesantren tidak hanya menciptakan interaksi dan interpretasi keilmuan yang lebih inteks dan berpaduan antara ilmu-ilmu agama dengan ilmu-ilmu umum yang berkaitan dengan sains dan teknologi, tetapi juga penguasaan terhadap sains-teknologi untuk kepentingan/ keperluan dalam masa industri dan pasca industry (Azra, 2000).

Hal ini jelas penekanan santri pada penguasaan kognitif. Santri dituntut besar menggunakan akal pikirnya dan intelektualnya. Lebih-lebih orientasinya pada pasar industri. Maka tidak mustahil anak diibaratkan seperti produk, padahal orientasi pendidikan Islam tidak hanya ilmu dan teknologi. Biasanya anak didik yang memfokusnya sains dan teknologi akan mengabaikan moralnya. Seperti yang terjadi di negara-negara Barat yang orientasinya bagaimana menguasai sains dan teknologi untuk menghasilkan sesuatu yang bernilai materi sehingga mengarah kepada materialisme. Azra (2002) mengatakan: "Proses-proses pendidikan yang berlangsung lebih menekankan pada pengembangan ranah kognitif peserta didik dan sebaliknya cenderung mengabaikan ranah afektif dan psikomotorik. Akibatnya sekolah lebih berfungsi sebagai tempat pengajaran dari pada pendidikan, banyak sekolah gagal membentuk peserta didik yang memiliki karakter dan kepribadian".

Maka apa yang dikemukakan Azra (2002) benar, "Sekolah cenderung menghasilkan manusia Indonesia yang mengalami kepribadian yang terbelah dengan segala implikasi dan dampak negatifnya dalam kehidupan individual dan sosial". Krisis ekonomi yang terjadi di Indonesia telah meluas kepada krisis moralitas. Banyaknya tawuran dikalangan pelajar menunjukkan pendidikan moral perlu dipertanyakan. Banyak kalangan melihat adanya krisis spiritual yang dihadapi para siswa.

Zaman globalisasi yang menimbulkan kekacauan sosial dan banyak orang yang tersingkir dan sebagainya. Menurut Azra (1998), "Pembentukan watak menjadi sangat penting, orang-orang yang berkepribadian kuat, yang berkarakter akan lebih tangguh dalam menghadapi globalisasi atau dampakdampak negatifnya". Watak dan kepribadian seseorang sekarang ini dipandang sangat menentukan kesuksesan dalam perjuangan hidupnya. Kesuksesan tidak hanya ditentukan oleh IQ yang cerdas saja. Jika hanya mengandalkan kecerdasan intelektual seseorang cenderung mudah putus asa bila menghadapi berbagai kesulitan. Kecerdasan emosional dan spiritual memiliki peran yang penting bagi keberhasilan seseorang. Banyak orang yang cerdas tetapi ia tidak berhasil menemukan kebahagiaan dalam hidupnya. Di sini pendidikan emosional dan spiritual sangatlah perlu.

Dengan demikian dalam pandangan Azra (2002), bagaimana pesantren mewujudkan generasi muda yang berkualitas secara kognitif, afektif dan psikomotorik. Identitas pesantren harus dipertahankan dalam sistem pendidikannya. Berkaitan dengan sistem pendidikan pesantren seperti halaqoh. Secara historis, pendidikan Islam yang diselenggarakan di Masjid berlangsung dalam halaqoh-halaqoh. Lingkaran belajar yang melibatkan pembahasan intensif dan hubungan yang erat antara guru dengan peserta halaqoh menjadi karakter penting dalam pembinaan dan pembentukan caloncalon ulama. "Banyak ulama terkemuka Indonesia sejak abad ke-17 sampai abad ke20 yang belajar di Makkah dan Madinah memperoleh pendidikan dari sistem halaqohhalaqoh yang ada di Masjid Al-Haram Makkah 
dan Masjid Al-Nabawi Madinah." Mereka juga belajar secara pribadi langsung di rumah guru. Dalam halaqoh, hubungan personal terbentuk dan menjadi ikatan yang menghubungkan mereka satu dengan yang lain. Para guru dikenal secara pribadi oleh masing-masing murid. Mereka berusaha mengenali kebutuhan dan bakat khusus masing-masing murid. Menurut Azra (2002): "Hal tersebut tidak dapat diremehkan. Metode belajar tersebut merupakan ciri pesantren dalam proses pendidikan yang sesungguhnya".

Oleh sebab itu, saat ini banyak kerinduan dikalangan orang tua untuk memilih atau mendapatkan pendidikan yang Islami. Pendidikan agama yang ada di sekolahsekolah umum tidak diyakini sehingga mereka menyerahkan anaknya ke pesantren. "Karena pesantren dengan proses pendidikannya selama 24 jam penuh dipandang mampu menjinakkan anak-anak mereka dari dislokasi sosial (pergeseran sosial) yang muncul dewasa ini sebagai akses globalisasi nilai-nilai" (Azra, 2001).

Ini menunjukkan proses pendidikan di pesantren tersebut sangat efektif bagi pembentukan watak dan kepribadian di samping pengisian ilmu-ilmu agama. Oleh sebab itu proses pedagogik dalam pesantren perlu dilestarikan dan dikembangkan.

\section{KESIMPULAN}

Modernisasi yang dilakukan pesantren dalam bentuk kelembagaan seperti pertanian, perikanan atau sekolah-sekolah umum di lingkungan pesantren telah menimbulkan kemerosotan identitas pesantren. Di samping itu, ekspansi pesantren tersebut tanpa memperhitungkan kebutuhan berbagai sektor masyarakat khususnya lapangan kerja sehingga tamatan pesantren tersebut tidak mampu menemukan tempat yang pas dalam masyarakat. Azra mengemukan eksperimen tersebut telah menimbulkan kekhawatiran dari berbagai kalangan yang ingin mempertahankan identitas pesantren sebagai lembaga pendidikan untuk Tafaqquh fi Al-Din sehingga pesantren tidak akan dapat memenuhi tugas pokoknya untuk mereproduksi ulama. Azra mengharapkan pesantren harus menumbuhkan apresiasi yang sepatutnya terhadap semua perkembangan yang terjadi di masa kini dan mendatang, sehingga dapat memproduksi ulama yang berwawasan luas. Pesantren merupakan tumpuan utama dari lembaga pendidikan Islam yang memungkinkan untuk melahirkan atau memproses ulama. Menurut Azra masalah ulama, kaderisasi dan reproduksi ulama berkaitan erat dengan masalah pesantren.

Adanya gagasan modernisasi pesantren yaitu dengan memasukkan ilmu-ilmu sekuler (umum) ke dalam kurikulum pesantren telah menimbulkan permasalahan. Menurut Azra, muncul persoalan tentang bagaimana tepatnya secara epistimologi menjelaskan ilmu-ilmu empiris atau ilmu-ilmu alam dari kerangka epistimologi Islam. Azra juga menambahkan, kurikulum yang berorentasi kekinian terus berlanjut dikhawatirkan pesantren tidak mampu lagi memenuhi fungsi pokoknya yaitu menghasilkan manusia-manusia santri. Oleh karena itu menurut Azra pesantren harus mengkaji ulang secara cermat dan hati-hati berbagai gagasan modernisasi tersebut dan pesantren harus lebih mengorientasikan peningkatan kualitas para santrinya kearah pengusaan ilmu-ilmu agama.

Dalam pesantren modern yang menggunakan sistem kurikulum yang ketat dan kaku, dengan tujuan untuk mengorientasikan penguasaan kognitif semata, menurut Azra, dapat mengakibatkan proses pembentukan watak dan kepribadian santri terabaikan. Azra juga mengharapkan, bahwa pesantren untuk tetap mempertahankan metodologinya, yaitu proses pengajaran yang berlangsung itu lebih merupakan learning, ta'lim daripada tarbiyah yang terlihat formal. Ta'dib lebih luas pengertiannya yaitu proses inkulturasi, proses pembudayaan anak didik, sehingga pesantren dapat mampu membentuk dan menyiapkan anak didik menjadi muslim yang baik. Oleh karena itu motode halaqah dalam pesantren harus dipertahankan sebab dengan metode tersebut seorang guru dapat mengenali kebutuhan dan bakat khusus masing-masing murid. Menurut Azra metode belajar tersebut merupakan ciri pesantren dalam proses pendidikan sesungguhnya.

Meskipun ada kekhawatiran tersendiri dalam pergeseran dari pesantren tradisional menjadi pesantren modern, namun aktualisasi modernisme lembaga pendidikan 
Islam khususnya pondok pesantren menjadi keniscayaan yang perlu dipertimbangkan guna menjawab sebuah tantangan global. Kekhawatiran tersebut tentu berhubungan dengan identitas pesantren yang bisa saja akan tergerus dengan nilai-nilai global yang begitu bebas. Namun demikian, nilai modernitas yang dibarengi dengan kesiapan jati diri pesantren akan memperkokoh identitas pensatren di kancah dunia. Tentu hal tersebut harus dibarengi dengan kuatnya identitas diri pesantren sebagai lembaga pendidikan yang mampu berdiri dan berkembang dalam situasi apapun.

\section{DAFTAR PUSTAKA}

Al Akbar, N. (2016). "Menjinakkan" Globalisasi: Studi Kritis Globalisasi Budaya Pada Pementasan Sendratari Ramayana Borobudur". Jurnal Ilmu Sosial Mamangan, 5(1), 1-12.

Azra, A. (1998). Rekonstruksi Kritis Ilmu dan Pendidikan Islam. In A. M. Mulkhan \& et.al (Eds.), Rekonstruksi Pendidikan dan Tradisi Pesantren, Religiutas IPTEK. Yogyakarta: Fak. Tarbiyah IAIN Sunan Kalijaga dan Pustaka Pelajar.

Azra, A. (1999). Esai-Esai Intelektual Muslim Pendidikan Islam. Jakarta: Logos Wacana Ilmu.

Azra, A. (2000). Pendidikan Islam,Tradisi dan Modernisasi Menuju Melinium Baru. Jakarta: Logos Wacana Ilmu.

Departemen Agama. (2003). Pondok Pesantren dan Madrasah Diniyah; Pertumbuhan dan Perkembangannya. Jakarta: Direktorat Jenderal Kelembagaan Agama Islam, Depatemen Agama RI.

Dhofier, Z. (1982). Tradisi Pesantren, Studi Tentang Pandangan Hidup Kyai. Jakarta: LP3ES.

Fajar, M. (2010). Visi Pembaruan Pendidikan Islam. Bandung: Lembaga Pengembangan Pendidikan dan Penyusunan Naskah Indonesia /LP3NI.

Firdaus, \& Wekke, I. S. (2017). Pattern of Pesantren On Expanding of Smart, Hardworking and Ikhlas Characters in West Suamtera. In Seminar Pendidikan Transdisiplin (STEd 2017) (pp. 258265).

Hardiman, B. F. (1993). Kritik Ideologi, Pertautan Pengetahuan dan
Kepentingan. Yogyakarta: Kanisius. Kafrawi, H. (1978). Pembaharuan Sistem Pendidikan Pesantren. Jakarta: Cemara Indah.

Kartini. (1996). Pengantar Metodologi Riset Sosial. Bandung: Mandar Maju.

Mardalis. (1996). Metode Penelitian: Suatu Pendekatan Proposal. Jakarta: Bumi.

Muhaimin. (1993). Pemikiran Pendidikan Islam "Kajian Filosof Dan Kerangka. Dasar Operasionalnya." Bandung: Trigenda Karya.

Mulkhan, A. M. (2002). Nalar Spiritual Pendidikan, Solusi Problem Filosofis Pendidikan Islam. Yogyakarta: PT. Tiara Wacana Yogya.

Mun'im, Z. (2009). Peran Pesantren dalam Education for All di Era Globalisasi. Jurnal Pendidikan Islam (JPI), 1(1).

Rahardjo, M. D. (1982). Pergulatan Dunia Pesantren. Jakarta: LP3ES.

Sholihah, U. (2012). Peran ICT Dalam Modernisasi Pendidikan Pondok Pesantren. Cendikia; Journal of Education \& Society, 10(1), 15-27.

Solichin, M. M. (2014). Kebertahanan Pesantren Tradisional Menghadapi Modernisasi Pendidikan. Karsa, 22(1), 93-113.

Steenbrink, K. A. (1989). Pesantren, Madrasah,Sekolah. Jakarta: LP3ES.

Tafsir, A. (2011). Pendidikan Dalam Prespektif Islam. Bandung: Remaja Rosdakarya.

Tapondhadhai, A. T., Ansofino, \& Nazmi, R. (2012). Persepsi Masyarakat Petani Kelapa Terhadap Pendidikan Tinggi Anak di Kecamatan Siberut Barat, Kabupaten Kepulauan Mentawai. Jurnal Ilmu Sosial Mamangan, 1(2), 102-108.

Wahid, M., \& Zuhri, S. (1999). Masa Depan, Wacana Pemberdayaan dan Transformasi Pesantren. Jakarta: Pustaka Hidayah.

Yasmadi. (2002). Modernisasi Pesantren Kritik Nurcholis Madjid Terhadap Pendidikan Islam Tradisional. Jakarta: Ciputat Press. 